JOHN KINSELLA

\title{
FIRST LINES TYPED AT JAM TREE GULLY
}

To hold the walls of valley down-thrust limbs of York gum liminality, flakes of granite and lichen scored as sun inland, glitterati, this Toodyay stone broken where the building has opened precipice, erodability, that movement where we walk, dislocating weight of conversation, even meditation, to contravene our visibility, perched up on high, sidereal.

A drawing out, the day lessens, rampage of dead and living trees, entire collapsed structures, signs of fire as jam-tree bark blackened crumbles with touch, all working shadows thin up the hill, the hill. Kangaroos stir from their shady placesthe heat so intense at midday they don't do more than lift their head as you approach.

In the dirt, laterite smudgings, hard-baked patches of sand, coarsegrained breakdown of quartzite in its granoblastic glory, a sheen of mica and feldspar configuring a sandstone past, a declaration 
of origins; what grows in what was here before? It demands reconnection or the hill will despoil to its granite core and nothing more, nothing more. Dazzling anomaly of pyrites, breeze sharpened with "fool," "fool"... welcome here... don't cling together, give us roots to nest among, cling to.

Common bronzewings heavy across the blank of an arena we will fill with trees: sandy spectacle, where horses rounded on their tails: I see them twitch.

Internal fences down and out. Fewer divisions. To predict a fate, changes sweeping over an old old place; ringneck parrot feathers no divination. What has chiacked in place of undergrowth?

Weebills are here! And mistletoe birds have been where mistletoe fruits have prospered, have seeded jam trees, where nectar-hungry birds of many varieties test the hardy flowers drooping in swatches from thin, straining necks; the parasitic engenders its own chains of being. I am not asking to be part of it. With time, something will click, I have no idea what. No 
second-guessing, despite the weight

of hexagrams, I-Ching. What else

I might read. Weebills are here!

Horseshoes and sheep skulls strewn across the block.

Rare new growth, so late and odd. Fire wardens

watching afraid of vegetation? They have their own

version of prehistory, their own version of growth.

The making of place as a dynamic of couplings, as if love and trust are omens, odds in your favor. The sun burns but also fringes the leaves. 